\title{
Integrative survey for ant diversity: exhaustive deployment of several ant collection methods in Biological Education and Research Forest of Universitas Andalas, Indonesia
}

\author{
Henny Herwina ${ }^{1, *}$, Rijal Satria ${ }^{2}$, Yaherwandi $^{3}$, Yositaka Sakamaki ${ }^{4}$, Mairawita $^{1}$, \\ Diyona Putri ${ }^{5}$, Ahmad Efendi ${ }^{1}$, Yusuke Kusuhata ${ }^{4}$, Muhammad N. Janra ${ }^{2}$

\begin{abstract}
${ }^{1}$ Animal Taxonomy Laboratory, Biology Department, Faculty of Mathematics and Sciences, Universitas Andalas, Indonesia, ${ }^{2}$ Department of Biology, Faculty of Mathematics and Natural Sciences, Universitas Negeri Padang, Padang 25131, West Sumatra, Indonesia; ${ }^{3}$ Department of Pests and Plant Diseases, Faculty of Agriculture, Universitas Andalas, 25163 West Sumatra, Indonesia, ${ }^{4}$ Entomological Laboratory, Faculty of Agriculture, Kagoshima University, Korimoto 1-12-24 Kagoshima, 890-0065, Japan ; ${ }^{5}$ Department of Biological Sciences, Graduate School of Science and Engineering, Tokyo Metropolitan University, Tokyo, Japan
\end{abstract}

Received: March 8, 2021; Revised: June 21, 2021; Accepted: September 16, 2021

\begin{abstract}
A long period of ant sampling has been conducted in Biological Education and Research Forest (BERF), Universitas Andalas, West Sumatra, Indonesia by deploying several methods i.e. direct hand collection in rotten logs, at flowering plants and at bird nests, Quadra Protocol for sampling diurnal and nocturnal ground ants and subterranean trap for soil ants. A total of 100 ant species which taxonomically grouped into 41 genera, 15 tribes and eight subfamilies resulted from this study. Myrmicinae became subfamily with the most species recorded (46 species), after the Formicinae with 28 species and Ponerinae with 11 species. On the other hand, the rest subfamilies were represented with less species e.g. Dolichoderinae (6 species), Dorylinae (3 species), Pseudomyrmicinae (3 species), Ectatommine (2 species) and Ambliponinae (1 species). Pheidole was genus with the most species recorded (17 species) followed by Crematogaster (7 species) and Polyrhachis (6 species). Quadra Protocol became the most effective method to record ant species in this study (42 species), subsequently followed by purposive hand collection method (40 species), subterranean trap (10 species), direct collection in rotten logs (8 species), observation at flowering plants (8 species) or collection from within bird nests (4 species). Despite the robustness of inventory produced from this study, it is indicated that BERF area still holds more ant species that are not recorded by research done so far.
\end{abstract}

Keywords: Ant diversity, Biology Education and Research Forest, ground ants, subterranean ants, arboreal ants

\section{Introduction}

Ants are estimated to comprise around $30 \%$ of terrestrial faunal biomass in the world (Hölldobler and Wilson, 1990). Ants are essential ecological components as they have direct interaction with plants (Putri et al. 2016), soil organisms (Meer, 2012) and other organisms in the most of trophic levels. Their roles usually relate to seed consumption (Andersen, 1990; Majer, 1990) and dispersal (Majer, 1990). Acting as predators for pest insects (Choate and Drummond, 2011), ants retain equal value with other predators such as lady beetles, lacewings and mantis (Saleh et al., 2010; Sanda and Sunusi, 2014).

Ants have been recognized as a useful ecological indicator as similar as with bees, as they exist in abundant numbers and ubiquitously, even at a disturbed area (Andersen, 1990; Schreven at al., 2018; Munyuli, 2012). Ants are very sensitive to environmental disturbances, hence they rapidly respond to any change in their habitat
(Van Der Woude et al., 1997; Andersen, 1990). On the other hand, ants build stationary nests with limited foraging range, which helps with avoiding competition among species and colonies (Agosti et al., 2000).

Ants have become long-standing research objects. They are reported to have high diversity in tropical rainforest of Southeast Asia (Yamane, 1996; Chung and Maryati, 1996; Brühl et al, 1998; Idris et al., 2002). In Indonesia, ant diversity was studied from various locations in Java, such as at Bogor Botanical Garden, West Java, where 216 ant species inventoried (Ito et al., (2001); 48 species were recorded from conservation area in Kepulauan Seribu, Jakarta (Rizali et al., 2008); 37 species were reported from around Mount Krakatou in Sunda Strait (Asfiya et al., 2010. Meanwhile in Sumatra, 76 ant species were recorded from oil palm plantation in West Sumatra and Riau (Herwina et al., 2020), 27 ant species were collectively observed across altitudinal gradients in Mt. Talang, West Sumatra (Herwina et al., 2020), in addition to 18 species

\footnotetext{
* Corresponding author. e-mail: hennyherwina@sci.unand.ac.id.
} 
that were found associated with white germ in potato plantation of highland agricultural area (Herwina, 2020).

Universitas Andalas is located in Limau Manis, Pauh Subdistrict, approximately $15 \mathrm{~km}$ from the downtown of Padang City, West Sumatra Province. Universitas Andalas covers 500 -hectare area, where its forested surrounding is considerably representative to hold various topics of field research, including those in entomology. The prominent forested area is situated within the Biological Education and Research Forest of approximate 150-hectare area. The BERF site harbors lowland tropical rainforest connected with the Bukit Barisan Range (Rizaldi et al., 2018). It has been the ground for ant research since more than two decades ago (Herwina et al, 2018). This study aimed to trackback the progress of works on ants in Universitas Andalas campus complex, as well as to analyze the ecological aspects of ants, such as species diversity and composition.

\section{Materials and Methods}

\subsection{Study area and sampling methods}

The data used in this study was synthesized from published and unpublished works mainly conducted within Biological Education and Research Forest (hereinafter BERF), Universitas Andalas, Indonesia (GPS coordinates $1^{\circ} 00^{\prime} \mathrm{S}, \quad 100^{\circ} 30^{\prime} \mathrm{E}$; Figure 1). The samplings were undertaken at ten sites established between 250 to $450 \mathrm{~m}$ elevation in BERF, with measured temperature between 28 to $32^{\circ} \mathrm{C}$. Sampling sites can be detailed as Site 1 (permanent plots for plant ecological study, dominated by secondary vegetation and medium trees), Site 2 (water dam 1, located at forest edge with early successive vegetation), Site 3 (camping ground with grasses and tall trees), Site 4 (water dam 2 inside forested area of BERF), Site 5 (bushy area in the border of BERF), Site 6 (Puncak Ixora, a peak of small hill with big trees and other primary vegetation), and Site 7 (bushy area in adjacent to Site 1). Site 8 to 11 are located on the borderline between BERF and campus area, separated by concrete road and each marked with field station or research lodge. Methodology applied in preceding and recent works conducted at those sites can be summarized as follow (also see Table 1): at Site 1 to 6, quadra protocol for ant collection (Hashimoto et al., 2001), which repeated between 2013 to 2016 (unpublished); Site 7, subterranean trap and probe (Herwina et al., 2018); Site 8, rotten log ant collection (unpublished); Site 9, ant collection in bird nests (Herwina et al., 2021); Site 10, hand collection method (ongoing since 2010; unpublished); and Site 11, hand collection and recording ant visitation at flowering plants (2019, unpublished). The exact position of sampling sites in BERF can be seen in Figure 1 below.
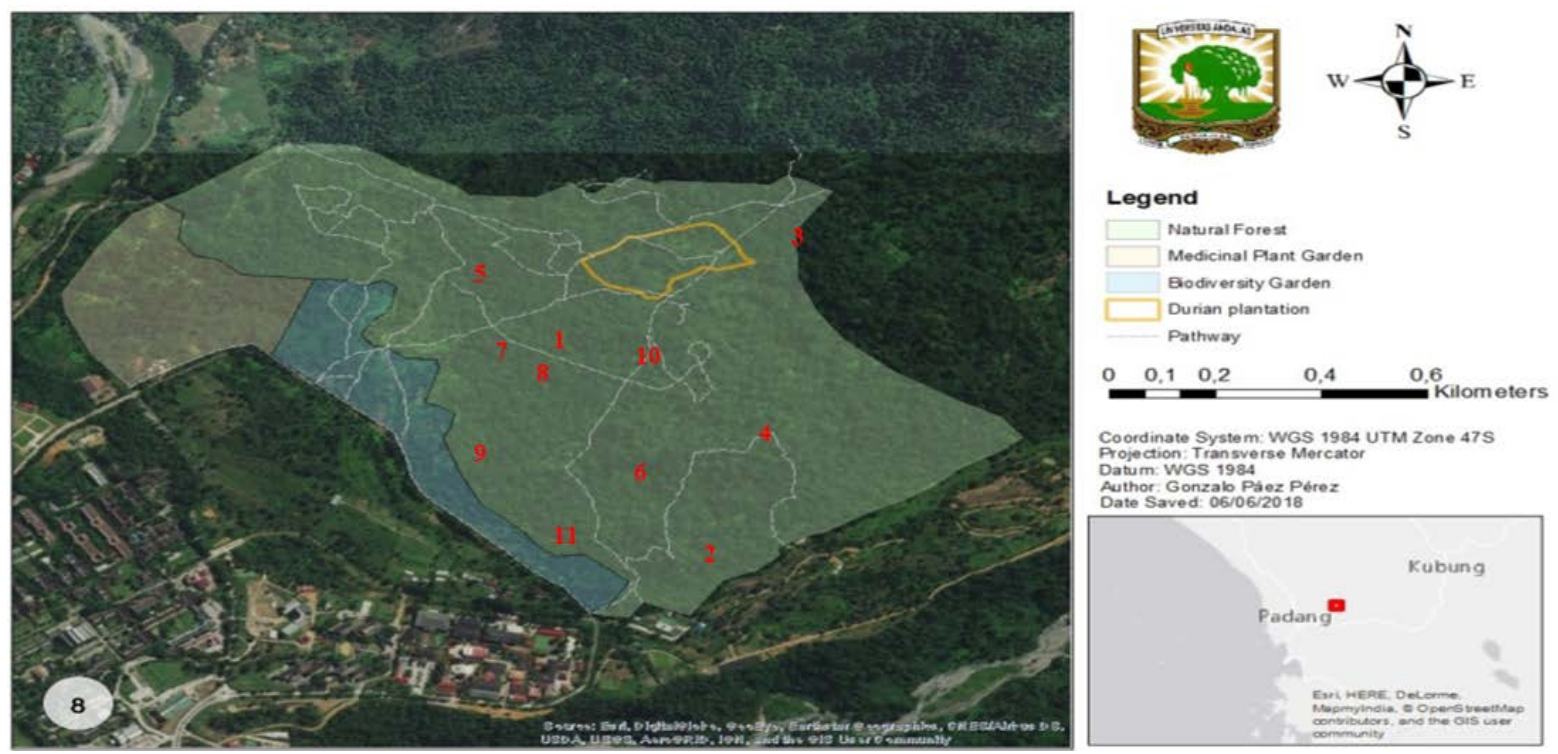

Figure 1. Sampling sites for ant collection at Biological Education and Research Forest (BERF), Universitas Andalas. No 111 = sites numbers.

\subsection{Species Species Identification}

Sampled ants were sorted to morphospecies and genus level before prepared according to the standard preparation for ant specimen. Identification process was guided by appropriate literatures (Hashimoto, 2003; Jaitrong, 2011; Bolton, 2014) in addition to being compared with specimen housed at the Animal Taxonomy Laboratory of Biology Department, Universitas Andalas. Any specimen resulted from the works listed here was also stored in this place.

\subsection{Data Analysis}

Ants were grouped into their taxonomic orders as follows; species, genus and subfamily. Individual and species number were counted and tabulated. The ShannonWiener formula (Magurran, 2004) was used to calculate species diversity, while Estimate S Veers. 9.0 was for calculating the rarefaction curves of observed and estimated number of ant species. The formula for species diversity is below:

$$
H^{\prime}=-\sum_{i=1}^{n} p i \ln p i
$$

$\mathrm{H}^{\prime}=$ Species diversity index

$\mathrm{pi}=$ Total proportion of sample from the $\mathrm{i}^{\text {th }}$ species 


\section{Results and Discussion}

This study recorded a total of 100 ant species from 43 genera and eight subfamilies. They were identified from overall sampling efforts within BERF that spanned from 2010 to 2019 (Table 1, Apendix 1). The subfamily Myrmicinae was observed with the highest species number (46 species), followed by 28 species of Formicinae, 11 species of Ponerinae, 3 species each for Dorylinae and Pseudomirmicinae, two species of Ectatomminae and one species of Ambliponinae (Appendix 1). Myrmicinae was frequently reported as family with the highest species number observed in many previous studies (such as
Shattuck, 1999; Herwina et al., 2013). Pheidole was genus with the most species recorded (17 species) in this study, followed by Crematogaster (7 species) and Polyrhachis (6 species). Pheidole was reported as genus with the highest species number in previous studies, including among subterranean ants (Herwina et al., 2018), within the species inventory from conservation forest and oil palm plantation in West Sumatra (Herwina et al., 2020) or from the protected forest in Riau (Putri et al., 2021). Crematogaster and Polyrhachis were also previously recorded as genera with high species number (Herwina et al., 2020).

Table 1. Sampling times, sites, methods, total number of species (S), total number of individuals (N), species increment (SI), and species accumulation (SA) synthesized from works on ants in BERF, Universitas Andalas

\begin{tabular}{|c|c|c|c|c|c|c|c|}
\hline Site \# & Time & Site remark & Methodology & $\mathrm{S}$ & $\mathrm{N}$ & SI & SA \\
\hline 1 & 2013 & Permanent plots inside primary forest & Quadra protocol & 25 & 336 & 0 & 25 \\
\hline 2 & 2014 & Water dam 1 , secondary forest & Quadra protocol & 34 & 1289 & 12 & 37 \\
\hline 3 & 2014 & Camping ground, open grassland with trees & Quadra protocol & 35 & 1510 & 12 & 49 \\
\hline 4 & 2014 & Water dam 2, secondary forest & Quadra protocol & 19 & 1121 & 0 & 49 \\
\hline 5 & 2016 & Bushes & Quadra protocol & 32 & 931 & 13 & 62 \\
\hline 6 & 2016 & Hilly forested area & Quadra protocol & 42 & 2316 & 16 & 78 \\
\hline 7 & 2017 & Bushes and thickets & Subteranean ant collection & 10 & 369 & 3 & 81 \\
\hline 8 & 2018 & Primary forest interior & Rotten log ant collection & 8 & 62 & 4 & 85 \\
\hline 9 & 2018 & Forest edge & Collection from bird nests & 4 & 19 & 1 & 86 \\
\hline 10 & 2010, 2012, 2018 & Primary forest interior & Hand collection applied purposively & 40 & - & 14 & 100 \\
\hline 11 & 2019 & Forest edge & Hand collection, photography documentation & 8 & - & 0 & 100 \\
\hline
\end{tabular}

The inventory of ant species and subfamilies recorded in this study exceeded any previous study from other locations in West Sumatra, which included natural reserves, agricultural and household area. The BERF, in overall, can be considered as good habitat for ants, as high species diversity observed in this study $\left(\mathrm{H}^{\prime}=3.25\right.$, Table 1$)$ . The ants recorded here were more diverse than those observed at white germ and potato plantation in Sumatran highland agricultural area (Herwina et al., 2020c), at oilpalm plantations and its conservation forest in Solok Selatan, West Sumatra (Herwina et al., 2020d), at some altitudes of Mount Talang, West Sumatra (Herwina et al., 2020e), or at several islands offshore of Sulawesi (Asfiya et al., 2010).

Site six contributed the highest among other sites, in terms of collecting 2,316 ant individuals that identified into 42 species recorded and increased 16 new records into the species accumulation record (Table 1$)$. Site $3(1,510$ individuals, 35 total species, 12 new records), Site 2 (1,280 individuals, 34 total species, 12 new records) and Site 5 (931 individuals, 32 total species, 13 new records) were also significantly increasing species inventory to BERF area. The works on Site 10 and 11 were majority based on sporadic rapid assessment on ant species without paying much attention on collecting individual, hence no exact number provided for collected individual. The work on Site 10, however, recorded total 40 species with additional 14 new records to the BERF's ant species inventory. In addition to sampling efforts and methodology applied in collecting ants, physical-ecological factors were also thought to play role in having high sampling result. Sites with high individual number, total species and/or species increment (Site 2, 3, 4, 5, 6 and 10) were with denser secondary or primary cover, thicker leaf litter coverage on ground surface and more organic resources needed by ants than the other sites. The abundance of organic materials within the tropical vegetated area are useful for food, nesting site or other purposes for ants; hence the high ant diversity and population found in this type of habitat (Rizali et al., 2008; Sabu et al., 2008; Souza-Campana et al., 2017).

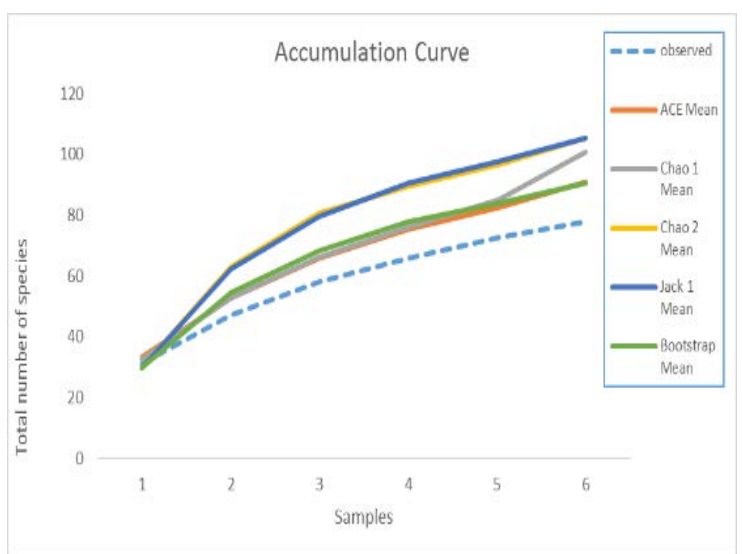

Figure 2. Accumulation curve of ant species collected by using quadra protocol at BERF

When counting the result method-wise, there was difference observed on the number of species resulted from each sampling method. Quadra protocol singly and remarkably accumulated a total of 78 ant species from six sites within the BERF area (Figure 2). Moreover, the 
computerized calculation performed using the data from quadra protocol provided estimation curve that predicted the possibility of actual number of $85-100$ ant species could be recorded at BERF if this method continuously applied. Quadra protocol involved thorough sampling procedure by simultaneously applying four collection techniques (hand collection, leaf litter sifting, soil core sampling and honey bait trap) within three sections of a $180 \mathrm{~m}$ transect. Hence, the techniques can be complimentary in collecting various ants with different life habits, instead of single technique or method that focus on one specific life habit. Given the species increasing trend that showed in Figure 2, indicated that further sampling efforts will potentially enrich the inventory of ant species in BERF.

Lophomyrmex bedoti was frequently collected in BERF (82\%), along with Pheidole aristotelis and Pheidole sp 3. of HH (73\% each), tailed by Diacamma holosericum and Acanthomyrmex ferox (64\%). Lophomyrmex was reported as generalist foragers and tropical climate specialist, which explain their successfulness in adapting to various habitats (Brown, 2000). Genus Pheidole was recorded with many species in this study, while $D$. holosericum and A. feroxs were the two species with prominent frequency. All of these taxa were collected using quadra protocol, which may emphasize the effectiveness of this sampling method to detect common and abundant ant species.
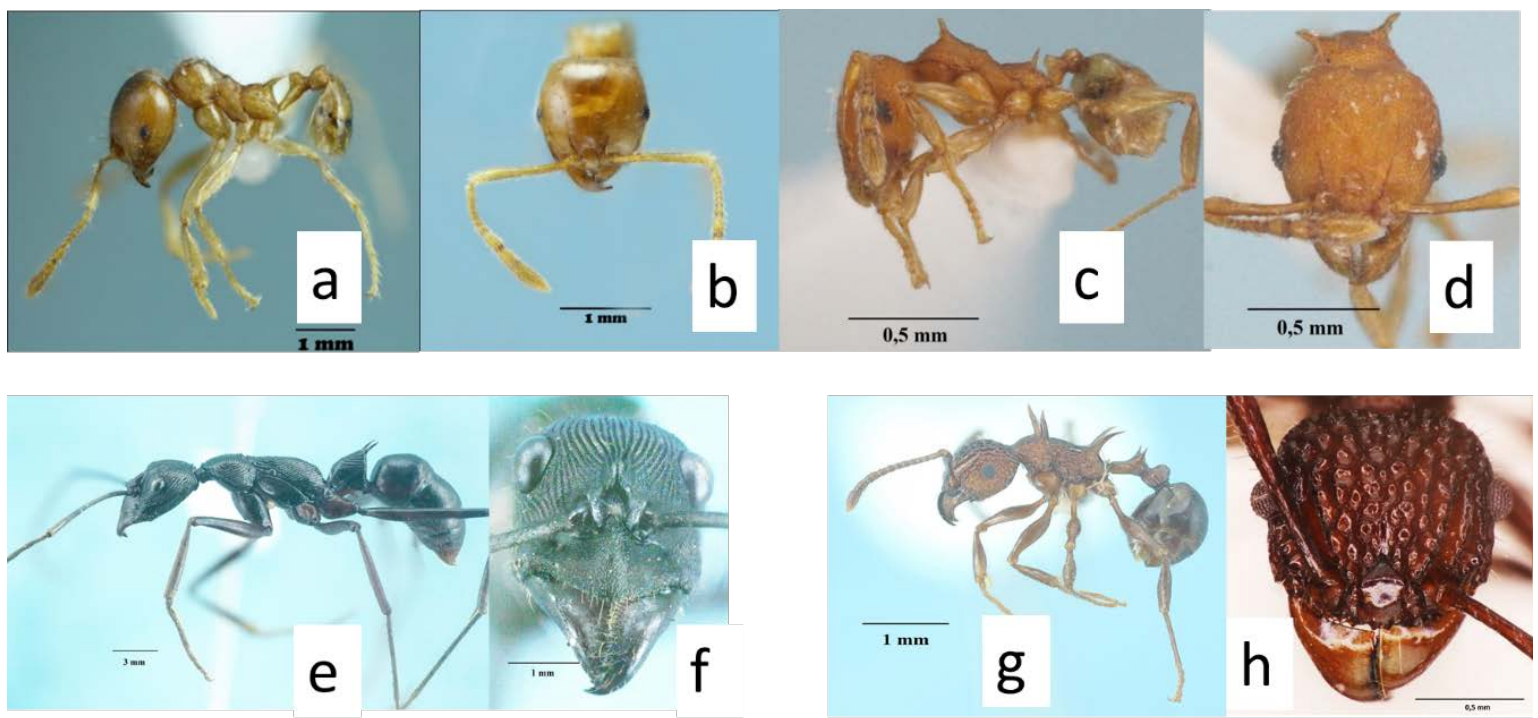

Figure 3. Abundant ant species in BERF (lateral and anterior-rostral aspect). A,b = Lophomyrmex bedoti. C,d = Pheidole aristotelis, e,f $=$ Diacamma holocericum, g,h = Acanthomyrmex ferox.

Diacamma ants were observed to prefer the secondary portion of BERF, similarly with A. ferox. It is thought to be related with their feeding habit and in connection to the resource available in such secondary habitat. The first taxon mainly consists of predatory species, while the later more of seed harvester (Brown, 2000). Some species were infrequently observed at one or a few sites with a handful individuals collected. These included Dolichoderus spp., Aenictus spp., Gnamptogenys coxalis, Camponatus spp., Odontomachus minangkabau, O. rixoxus, Carebara cf. affinis, Meranoplus mucronatus, Crematogaster medigmiani, Paratrechina sp. 1 or Anoplolepis gracilipes (Appendix 1).

The current study also recognized the existence of alien, tramp and invasive ant species from sites in BERF, i.e. Tapinoma melanocephalum, Anoplolepis gracilipes, and Paratrechina longicornis. These categories are attached to species that extend their distribution outside their original range by adapting and invading new territory (Pfeiffer et al., 2008). The presence of alien, tramp and invasive ant species in BERF gave strong indication of interference incurred from high human activities, which in many cases, negatively impacts the habitat for wildlife. The movement and distribution of alien, tramp and invasive species have been thought to be mediated by human activities (Pfeffer et al., 2008; Wetterer 2009, 2010). Since these alien, tramp and invasive species have good adaptability to new or disturbed habitats, they can also negatively influence the native communities (Pfeffer et al., 2008). Hence, from the ecological standpoint of ants, this study can provide further recommendation to reduce human interference within the BERF area in order to maintain better habitats therein.

\section{Conclusion}

Combining some collection methods for sampling ant show significant species number can be recorded at Biological Education and Research Forest of Universitas Andalas. The total species number accumulated in this study was the highest among other studies reported from Sumatra. Quadra Protocol, a standardized method for rapid assessment of ants, collected prominent number of species among other methods listed in this study as well as effective to detect frequent and abundant ant species. The analysis on the procured data indicates the possibility to record more ant species given the field exploration continued. Alien, tramp and invasive ant species were also observed during the study, indicated existing interference incurred from human activities within BERF.

\section{Acknowledgements}

We would like to express our gratitude to Seiki Yamane (Kagoshima University) for his valuable assistance in identifying ant specimens. This research was 
funded by Universitas Andalas’ Research Funding Scheme with contract number T/16/UN.16.17/PP.OKKRP2GB/LPPM/2019 on behalf Henny Herwina.

\section{References}

Agosti D, Majer JD, Alonso LE and Schultz TR. 2000. Ants: standard methods for measuring and monitoring biodiversity. Biological diversity hand book series. Washington \& London, 280 pp.

Andersen AN. 1995. Measuring more of biodiversity: genus richness as a surrogate for species richness in Australia ant faunas. Biol Conserv, 73: 39-43.

Andersen AN. 1990. The use of ant communities to evaluate change in Australian terrestrial ecosystems: a review and a recipe. Proc. Ecol. Soc. Aust., 16: 347-357.

Asfiya W, Ubaidillah R and Yamane S. 2010. Ant (Hymenoptera: Formicidae) of The Krakataus and Sebesi and Sebuku Islands. Treubia, 36: 1 - 9 .

Bestelmeyer BT and Wiens JA. 2001. Ant biodiversity in semiarid landscape mosaics: the consequences of grazing vs. natural heterogeneity. Ecol Appl, 11: 117-126.

Bolton B. 1994. Identification Guide to The Genera of the World. Hardvard University Press. London.

Bolton B. 2014. New General Catalogue of the Ants of The World. Harvard University Press. London.

Brown Jr WL. 2000. Diversity of Ants. In: D. Agosti, J. Majer, L. E. Alonso \& T. R. Schultz (Eds), Ants: standard methods for measuring and monitoring biodiversity. Biological diversity hand book series. Washington \& London.

Bruhl CA, Gunsalam G and Linsemair KE. 1998. Stratification of ants (Hymenoptera, Formicidae) in primary rain forest in Sabah, Borneo. J Tropical Ecol, 14: 285-297.

Cadotte MW, Carscadden K and Mirotchnick N. 2011. Beyond species: functional diversity and the maintenance of ecological processes and services. J App Ecol, 48: 1079-1087.

Chapin FS, Zavaleta ES, Eviner VT, Naylor RL, Vitousek PM, Reynolds HL, Hooper DU, Lavorel S, Sala OE, Hobbie SE, Mack MC and Diaz S. 2000. Consequences of changing biodiversity. Nature, 405.

Choate B and Drummond F. 2011. Ants as biological control agents in agricultural cropping systems. Terr Arthropod Rev, 4:157-180

Chung AY and Maryati M. 1996. A comparative study of the ant fauna in primary and secondary forest in Sabah, Malaysia. In: Edward DS, Booth WE, Choy SC (eds). Tropical Rainforest Research-Current Issues. Kluwer Academic, Dodrecht.

Colwell RK. 2013. Estimates: Statistical estimation of species richness and shared species from samples. Version 9. User's Guide and application published at: http://purl.oclc.org/estimates.

Fittkau EJ and Klinge H. 1973. On biomass and trophic structure of the central Amazonian rain forest ecosystem. Biotropica, 5: 214.

Hashimoto Y. 2003. Identification Guide to the Ant Subfamili of Borneo. Tools for Monitoring Soil Biodiversity in The ASEAN Region. DarwinInitiaive.

Herwina H, Nasir N, Jumjunidang and Yaherwandi. 2013. The composition of ant species on banana plants with Banana Bunchytop virus (BBTV) symptoms in West Sumatera, Indonesia. Jurnal Asian Myrmicology, 5: 151-161.
Herwina H, Satria R, Yaherwandi and Sakamaki Y. 2018. Subterranean ant species diversity (Hymenoptera: Formicidae) in Educational and Biological Research Forest of UniversitasAndalas. J Ent Zool Studies, 6 (1) 1: 720-1724.

Herwina H, Satria R and Mairawita. 2021. Wajah-wajah Semut Eksotis di Hutan HPPB. Rajawali Pers. Depok.

Herwina H, Mairawita, Yulvita L, Putri P, Satria R, Janra MN, Yaherwandi and Sakamaki Y. 2020 Ant Species Composition (Hymenoptera: Formicidae) at a Highland Agricultural Area for Wheat and Potato in Alahan Panjang, West Sumatra. IOP Conf. Series: Earth and Environmental Science, 515: 012018.

Herwina H, Sakamaki Y, Satria S and Janra MN. 2020. Grounddwelling ants species diversity (Hymenoptera: Formicidae) at conservation forest and oil-palm plantation in Sumatra, Indonesia. J Ent Res, 44 (1): 113-120

Herwina H, Dari MW, Yaherwandi and Kojima J. 2020. Altitudinal gradients of ant species diversity (Hymenoptera: Formicidae) in Mount Talang, West Sumatra, Indonesia. J Ent Res, 44 (3): 469-474.

Herwina H, Janra MN, Anita F, Mairawita, Yaherwandi. 2021. Are Bird Nest the habitat for Ants? Implication from Ant Inventory (Hymenoptera: Formicidae) across Various Bird Nests. IOP Conf. Series: Earth and Environmental Science, 748: 012036.

Hölldobler B and Wilson EO. 1990. The Ants. Belknap Press. Harvard University Cambridge.

Idris AB, Nor SM and Rohaida R. 2002. Study on Diversity of Insect Communities at Different Altitudes of Gunung Nuang in Selangor, Malaysia. J Biol Sci, 2: 505-507.

Ito F, Yamane S, Eguchi K, Noerdjito W A, Kahono S, Tsuji K, Ohkawara K, Yamauchi K, Nishida T and Nakamura K. 2001. Ant Species Diversity in Bogor Botanic Garden, West Java, Indonesia, with Descriptions of Two New Species of the Genus Laptanilla (Hymenoptera, Formicidae). Tropics, 10 (3): 379-404.

Jaitrong W. 2011. Identification Guide to The Ant Genera of Thailand. Thailand National Science Museum Press. PathumThani. 115 pp.

Janra MN, Herwina H, Febria FA Darras K and Mulyani Y A. 2019. Knemidokoptiasis in a Wild Bird, the Little Spiderhunter (Arachnotheralongirostracinireicollis), in Sumatra, Indonesia. $J$ Wildlife Dis, 55(2).

Kalif KAB, Azevedo-Ramos C, Moutingio P and Malcher SAO. 2001. The effect of logging on the ground-foraging ant community of eastern Amazonia. Stud Neotropical Fauna Env, 36: 215-219.

Magguran AE. 2004. Measuring Biological Diversity. Blackwell Science Ltd., UK.

Majer JD. 1990. Rehabilitation of disturbed land: long term prospects for the recolonization of fauna. - Proceedings of the Ecological Society of Australia, 16: 509-519.

Meer RV. 2012. Ant interactions with soil organisms and associated semichemicals. J Chem Eco.,l 38: 728-745.

Munyuli, TMB. 2012. Diversity of life-history traits, functional groups and indicator species of bee communities from farmlands of central Uganda. Jordan J Biol Sci, 5 (1): 1-14

Pfeiffer M, Tuck HC and Lay CT. 2008. Exploring arboreal ant community composition and cooccurrence patterns in plantations of oil palm Elaeis guineensis in Borneo and Peninsular Malaysia. Ecography, 31 (1): 21-32 
Putri D, Herwina H, Arbain A and Handru A. 2016. Ant species compositions in Macarangaspp trees at a conservation forest of palm oil plantation in West Sumatra, Indonesia. J Ent Zool Stud, 4 (1): 342-348.

Putri FA, Yulminarti, Herwina H, Janra MN, Satria R. 2021. Ant Community (Hymenoptera: Formicidae) at the Forest Park of Sultan Syarif Hasyim, Riau. IOP Conf. Ser.: Earth Environ. Sci. 757012079

Rizaldi, Novarino W, Nurainas, Idris M, Nurdin J and Mairawita. 2018. An Introduction to the Biology Education and Research Forest of Andalas University. www.repo.unand.ac.id.

Rizali A, Bos MM, Buchori D, Yamane S and Schulze CH. 2008. Ants in tropical urban habitats: the myrmecofauna in a densely populated area of Bogor, West Java, Indonesia. Hayati Biosci, 15: 77-84.

Sabu TK, Vineesh PJ and Vinod KV. 2008. Diversity of forest litter-inhabiting ants along elevations in the Wayanad region of the Western Ghats. J Insect Sci, 8: 1-14.

Saleh A, Ghabeish I, Al-Zyoud F, Ateyyat M and Swais M. 2010. Functional response of the predator Hippodamia variegate (Goeze) (Coleoptera: Coccinellidae) feeding on the aphid Brachycaudus helichrysi (Kaltenbach) infesting chrysanthemum in the laboratory. Jordan J Biol Sci 3 (1): 17-20

Sanda, NB and Sanusi M. 2014. Fundamental of Biological Control of Pest. IJCBS Review Paper, 1 (6): 1-11

Satria R, Kurushima H, Herwina H, Yamane S and Eguchi K. 2015. The trap-jaw ant genus Odontomachus Latreille (Hymenoptera: Formicidae) from Sumatra, with a new species description. Zootaxa, 4048 (1): 001-036.
Schreven SJJ, Perlett ED, Jarrett BJM, Marchanti NC, Harsanto FA, Purwanto A, Sykora KV and Harrison ME. 2018. Forest gaps, edge and interior support different ant communities in a tropical peat-swamp forest in Borneo, Asian Myrmecology, 10: 1-14

Shattuck .SO. 1999. Australian Ants: Their Biology and Identification. CSIRO Publishing, Australia.

Souza-Campana DR, Silva RR, Fernandes TT, Silva OGM, Saad LP and Morini MSC. 2017. Twigs in the litter as ant habitats in different vegetation habitats in Southeastern Brazil. Tropical Cons Sci, 10: 1-12.

Van Der Woude C, Andersen AN and Houswe APN. 1997 Ant communities as bioindicators in relation to fire management of spotted gum (Eucalyptus maculate Hook.) forest in south-east Queensland. Memoirs Museum Victoria, 56: 671-675.

Yamane S. 1997. A list of Bornean ants. In Inoue, T. and Hamid, A.A. (eds). General flowering of tropical rainforest in Sarawak. Canopy Biology Program in Sarawak (CBPS): series II. Center for Ecological Research, Kyoto University

Wetterer JK. 2009. Worldwide spread of the ghost ant, Tapinoma melanocephalum (Hymenoptera: Formicidae). Myrmecological News, 12: 23-33.

Wetterer JK. 2010. Worldwide spread of the tropical fire ant, Solenopsis geminata (Hymenoptera: Formicidae). Myrmecological News, 14: 21-35. 
Appendix 1. List of Subfamily, Tribe and Species of ants collected by using several methods in HPPB Universitas Andalas.

Sampling sites along with collection method as follows: site 1 = Permanent Plot inside BERF in 2014 (daytime Quadra Protocol), site 2 = Water Dam site point 1 in 2014 (daytime Quadra Protocol), site 3 = Camping ground, on 2014 (daytime Quadra Protocol), site 4 = Water Dam site point 2, in 2014 (Night Quadra Protocol), site 5 = bushy area, in 2016 (daytime Quadra Protocol), site 6 = Puncak Ixora, in 2017 (daytime Quadra Protocol), site 7 = bushy area and permanent plot, in 2017 (subterranean ant collection), site $8=$ BERF area, purposive sampling, in 2018 (rotten log ant collection), site 9 = BERF area, purposive sampling, in 2018 (bird nest ant collection), site $10=$ BERF area, purposive sampling, between 2010-2018 (hand collection), site $11=$ BERF area (ants as pollinator); $\mathrm{T}=\mathrm{total}, \mathrm{F}=$ ant frequency at sampling sites. asterisk $(*)$ indicate individual number for that species unavailable.

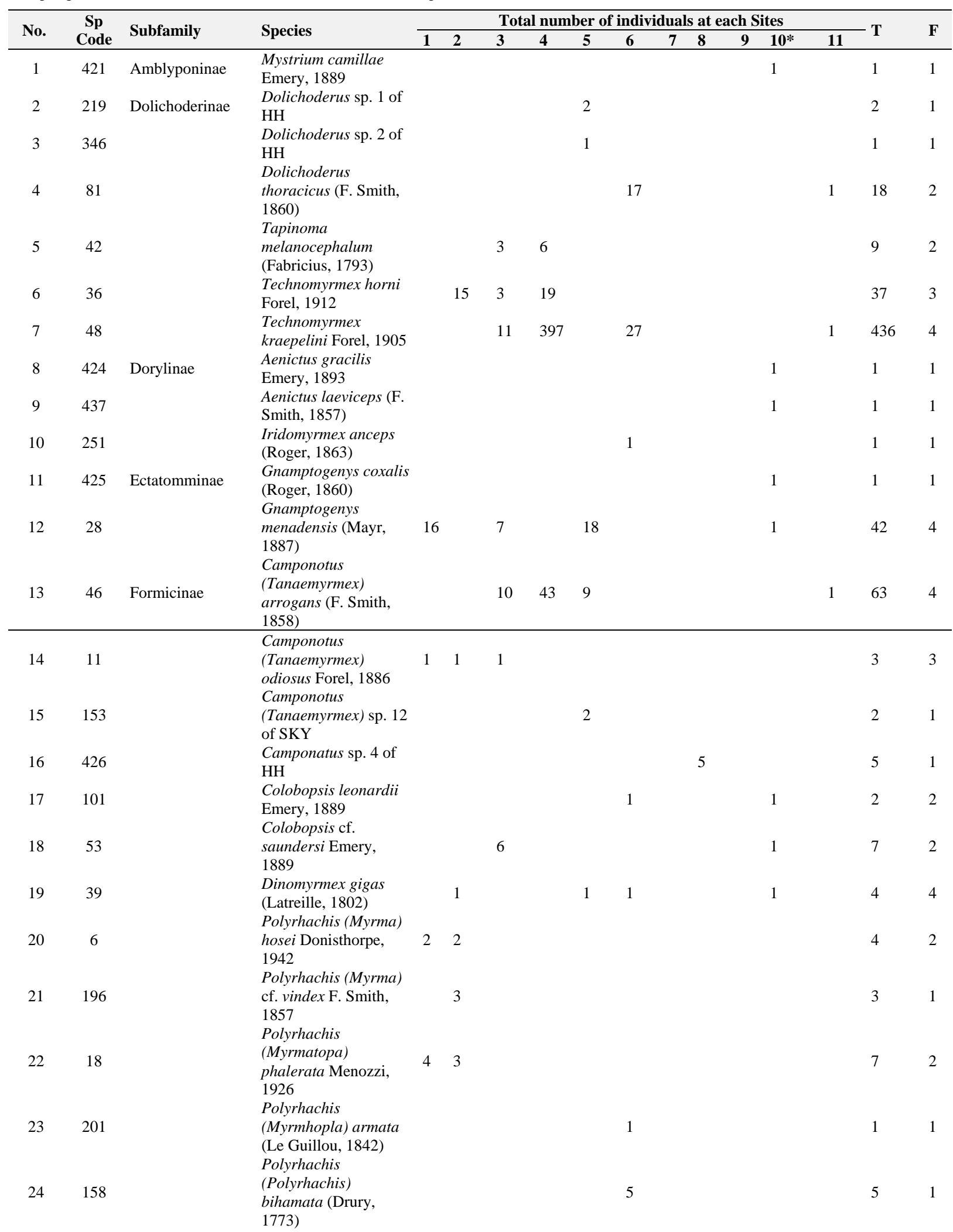


(C) 2021 Jordan Journal of Biological Sciences. All rights reserved - Volume 14, Number 5

\begin{tabular}{|c|c|c|c|c|c|c|c|c|c|c|c|c|c|c|c|c|}
\hline \multirow{2}{*}{ No. } & \multirow{2}{*}{$\begin{array}{c}\text { Sp } \\
\text { Code }\end{array}$} & \multirow{2}{*}{ Subfamily } & \multirow{2}{*}{ Species } & \multicolumn{11}{|c|}{ Total number of individuals at each Sites } & \multirow{2}{*}{$\mathbf{T}$} & \multirow{2}{*}{$\mathbf{F}$} \\
\hline & & & & 1 & 2 & 3 & 4 & 5 & 6 & 7 & 8 & 9 & $10^{*}$ & 11 & & \\
\hline 25 & 19 & & $\begin{array}{l}\text { Polyrhachis } \\
\text { (Polyrhachis) olybria } \\
\text { Forel, } 1912\end{array}$ & 4 & 12 & & & 1 & & & & & & & 17 & 3 \\
\hline 26 & 427 & & $\begin{array}{l}\text { Myrmoteras bakeri } \\
\text { Wheeler, } 1919\end{array}$ & & & & & & & & & & 1 & & 1 & 1 \\
\hline 27 & 55 & & $\begin{array}{l}\text { Myrmoteras sp. } 1 \text { of } \\
\text { HH }\end{array}$ & & & 1 & & & & & & & & & 1 & 1 \\
\hline 28 & 51 & & $\begin{array}{l}\text { Myrmoteras sp. } 2 \text { of } \\
\mathrm{HH}\end{array}$ & & & 1 & & & & & & & & & 1 & 1 \\
\hline 29 & 57 & & $\begin{array}{l}\text { Oechophylla } \\
\text { smaragdina } \\
\text { (Fabricius, 1775) }\end{array}$ & & & & & & 1 & & & & & 1 & 2 & 2 \\
\hline 30 & 2 & & $\begin{array}{l}\text { Anoplolepis gracilipes } \\
\text { (F. Smith, 1857) }\end{array}$ & 16 & 535 & & 244 & 17 & 2 & & & & 1 & & 815 & 6 \\
\hline 31 & 8 & & $\begin{array}{l}\text { Euprenolepis procera } \\
\text { (Emery, 1900) }\end{array}$ & 4 & & 6 & & 240 & 3 & & & 1 & & & 254 & 5 \\
\hline 32 & 410 & & $\begin{array}{l}\text { Nylanderia obscura } \\
\text { (Mayr, 1862) }\end{array}$ & & & & & & 16 & & & v & & & 16 & 1 \\
\hline 33 & 43 & & $\begin{array}{l}\text { Nylanderia sp. } 1 \text { of } \\
\mathrm{HH}\end{array}$ & & & 10 & 13 & 2 & 20 & & & & & 1 & 46 & 5 \\
\hline 34 & 13 & & $\begin{array}{l}\text { Nylanderia sp. } 2 \text { of } \\
\mathrm{HH}\end{array}$ & 4 & 132 & & 43 & & 2 & & & & & & 181 & 4 \\
\hline 35 & 44 & & $\begin{array}{l}\text { Nylanderia sp. } 3 \text { of } \\
\text { HH }\end{array}$ & & & 8 & 40 & & 5 & & & & & & 53 & 3 \\
\hline 36 & 421 & & $\begin{array}{l}\text { Paraparatrechina } \\
\text { butteli (Forel, 1913) }\end{array}$ & & & & & & 3 & & & & & & 3 & 1 \\
\hline 37 & 26 & & $\begin{array}{l}\text { Paraparatrechina sp. } \\
1 \text { of } \mathrm{HH}\end{array}$ & 4 & 7 & 5 & & 2 & 56 & & 1 & & & & 75 & 6 \\
\hline 38 & 38 & & $\begin{array}{l}\text { Paraparatrechina sp. } \\
2 \text { of HH } \\
\text { Paratrechina }\end{array}$ & & 2 & 8 & & & & & & & & & 10 & 2 \\
\hline 39 & 198 & & $\begin{array}{l}\text { longicornis (Latreille, } \\
\text { 1802) }\end{array}$ & & & & & & 4 & & & & & & 4 & 1 \\
\hline 40 & 10 & & $\begin{array}{l}\text { Pseudolasius sp. } 1 \text { of } \\
\text { HH }\end{array}$ & & 4 & & & & & & & & & & 4 & 1 \\
\hline 41 & 428 & Myrmicinae & $\begin{array}{l}\text { Pheidole acantha } \\
\text { Eguchi, } 2001\end{array}$ & & & & & & & & 12 & & & & 12 & 1 \\
\hline 42 & 16 & & $\begin{array}{l}\text { Pheidole aristotelis } \\
\text { Forel, } 1911\end{array}$ & 8 & 4 & 6 & 1 & & 32 & 37 & 22 & & 1 & & 111 & 8 \\
\hline 43 & 12 & & $\begin{array}{l}\text { Pheidole longipes } \\
\text { (Latreille, 1802) }\end{array}$ & 52 & 24 & 15 & & & 434 & & & & 1 & & 526 & 5 \\
\hline 44 & 103 & & $\begin{array}{l}\text { Pheidole plagiaria } \\
\text { Smith, } 1860\end{array}$ & & & & & 3 & & & & & & & 3 & 1 \\
\hline 45 & 307 & & $\begin{array}{l}\text { Pheidole quadrensis } \\
\text { Forel, } 1900\end{array}$ & & & & & 59 & 2 & & & 2 & & & 63 & 3 \\
\hline 46 & 429 & & $\begin{array}{l}\text { Pheidole cf. sauberi } \\
\text { Forel, } 1905\end{array}$ & & & & & & & & & & 1 & & 1 & 1 \\
\hline 47 & 7 & & Pheidole sp. 1 of $\mathrm{HH}$ & 1 & & 809 & & & 124 & $\begin{array}{l}13 \\
1\end{array}$ & & & 1 & & 1066 & 5 \\
\hline 48 & 14 & & Pheidole sp. 2 of $\mathrm{HH}$ & & 78 & 81 & 2 & 33 & & & & & & & 194 & 4 \\
\hline 49 & 29 & & Pheidole sp. 3 of HH & 22 & 74 & 38 & 5 & 5 & 20 & 1 & & & 1 & & 166 & 8 \\
\hline 50 & 4 & & $\begin{array}{l}\text { Pheidole sp. } 4 \text { (major } \\
\text { worker) of } \mathrm{HH}\end{array}$ & 6 & 8 & 2 & & 6 & & & & & & & 22 & 4 \\
\hline 51 & 197 & & Pheidole sp. 5 of $\mathrm{HH}$ & & & 39 & & & 79 & & & & & & 118 & 2 \\
\hline 52 & 171 & & Pheidole sp. 8 of $\mathrm{HH}$ & & & & & 264 & 421 & & & & & & 685 & 2 \\
\hline 53 & 174 & & Pheidole sp 11 of $\mathrm{HH}$ & & & 4 & & & & & & & & & 4 & 1 \\
\hline 54 & 192 & & Pheidole sp. 12 of HH & & & & & & & 2 & & & 1 & & 3 & 2 \\
\hline 55 & 193 & & Pheidole sp. 13 of $\mathrm{HH}$ & & & & & 1 & & & & & & & 1 & 1 \\
\hline 56 & 240 & & Pheidole sp. 14 of $\mathrm{HH}$ & & & & & 1 & & & & & & & 1 & 1 \\
\hline 57 & 396 & & Pheidole sp. 17 of $\mathrm{HH}$ & & & & & & 1 & & & & & & 1 & 1 \\
\hline 58 & 430 & & $\begin{array}{l}\text { Strumigenys chimaera } \\
\text { Bolton, } 2000 \\
\text { Strumigenys }\end{array}$ & & & & & & & & & & 1 & & 1 & 1 \\
\hline 59 & 21 & & $\begin{array}{l}\text { koningsbergeri Forel, } \\
1905\end{array}$ & 1 & 2 & & & & & & & & 1 & & 4 & 3 \\
\hline 60 & 275 & & $\begin{array}{l}\text { Srtumigenys sp. } 2 \text { of } \\
\mathrm{HH}\end{array}$ & & & & & & 1 & & & & & & 1 & 1 \\
\hline 61 & 17 & & $\begin{array}{l}\text { Acanthomyrmex ferox } \\
\text { Emery, } 1893\end{array}$ & 16 & 1 & 15 & 10 & 4 & 37 & & & & 1 & & 84 & 7 \\
\hline
\end{tabular}


(C) 2021 Jordan Journal of Biological Sciences. All rights reserved - Volume 14, Number 5

1007

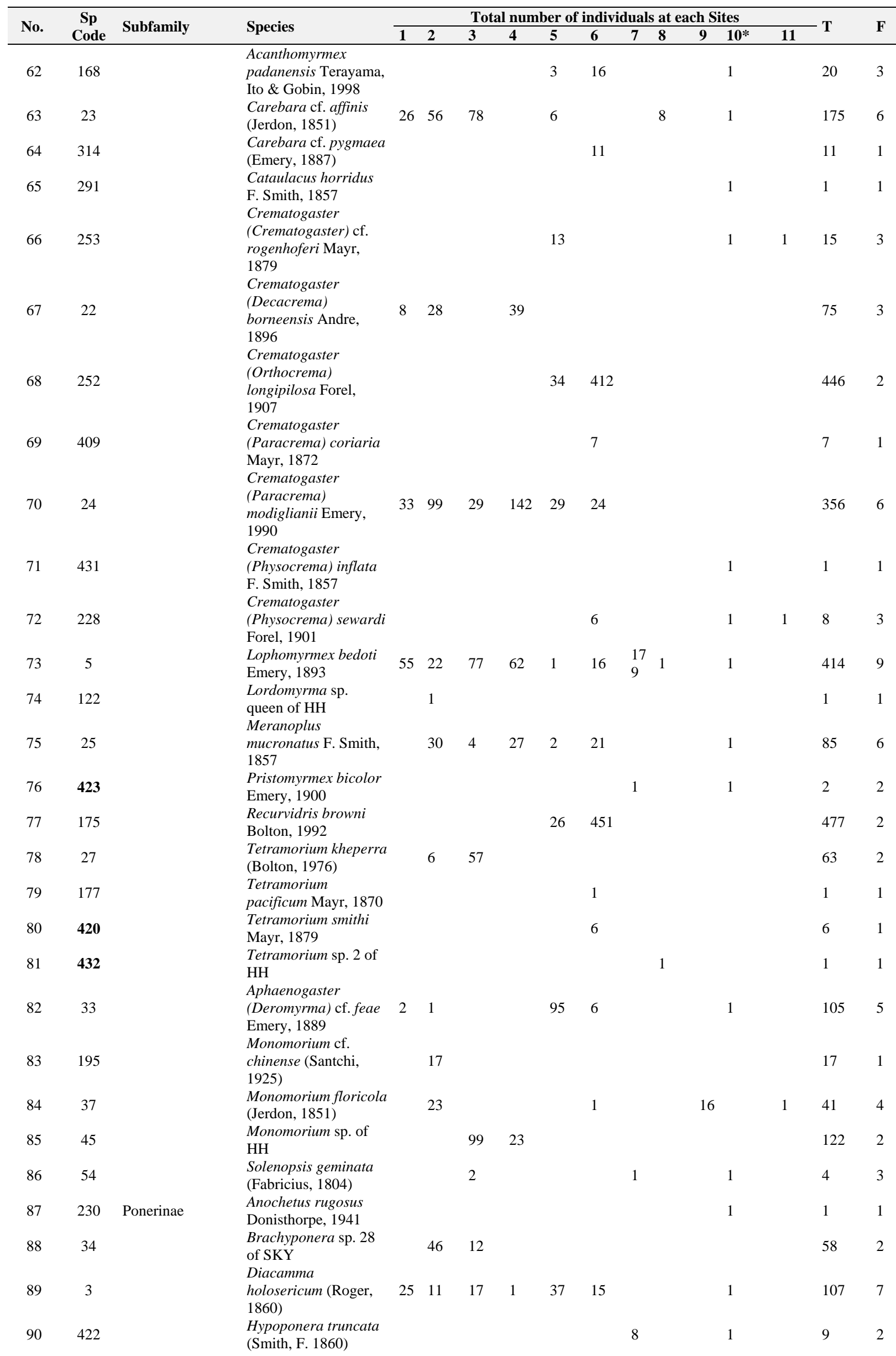




\begin{tabular}{|c|c|c|c|c|c|c|c|c|c|c|c|c|c|c|c|c|}
\hline \multirow{2}{*}{ No. } & \multirow{2}{*}{$\begin{array}{c}\text { Sp } \\
\text { Code }\end{array}$} & \multirow{2}{*}{ Subfamily } & \multirow{2}{*}{ Species } & \multicolumn{11}{|c|}{ Total number of individuals at each Sites } & \multirow{2}{*}{$\mathbf{T}$} & \multirow{2}{*}{$\mathbf{F}$} \\
\hline & & & & 1 & 2 & 3 & 4 & 5 & 6 & 7 & 8 & 9 & 10* & 11 & & \\
\hline 91 & 434 & & $\begin{array}{l}\text { Hypoponera sp. } 5 \text { of } \\
\text { HH }\end{array}$ & & & & & & & & 12 & & & & 12 & 1 \\
\hline 92 & 231 & & $\begin{array}{l}\text { Leptogenys parvula } \\
\text { Emery, } 1900 \\
\text { Odontomachus }\end{array}$ & & & & & & & & & & 1 & & 1 & 1 \\
\hline 93 & 185 & & $\begin{array}{l}\text { minangkabau Satria et } \\
\text { al., } 2015\end{array}$ & 1 & 1 & 3 & & & 7 & 8 & & & 1 & & 21 & 6 \\
\hline 94 & 20 & & $\begin{array}{l}\text { Odontomachus rixosus } \\
\text { F. Smith, } 1857\end{array}$ & 4 & 12 & 21 & 4 & 13 & & & & & 1 & & 55 & 6 \\
\hline 95 & 191 & & $\begin{array}{l}\text { Odontoponera } \\
\text { denticulata (F. Smith, } \\
\text { 1858) } \\
\text { Odontoponera }\end{array}$ & & & & & 1 & & 1 & & & & & 2 & 2 \\
\hline 96 & 1 & & $\begin{array}{l}\text { transversa (F. Smith, } \\
\text { 1857) }\end{array}$ & 21 & 28 & 22 & & & & & & & 1 & & 72 & 4 \\
\hline 97 & 435 & & $\begin{array}{l}\text { Pseudoneoponera } \\
\text { tridentata F. Smith, } \\
1858\end{array}$ & & & & & & & & & & 1 & & 1 & 1 \\
\hline 98 & 113 & $\begin{array}{l}\text { Pseudomyrmecin } \\
\text { ae }\end{array}$ & $\begin{array}{l}\text { Tetraponera attenuata } \\
\text { F. Smith, } 1887\end{array}$ & & & & & & & & & & 1 & & 1 & 1 \\
\hline 99 & 436 & & $\begin{array}{l}\text { Tetraponera } \\
\text { crassiuscula (Emery, } \\
1900 \text { ) }\end{array}$ & & & & & & & & & & 1 & & 1 & 1 \\
\hline 100 & 437 & & $\begin{array}{l}\text { Ietraponera } \\
\text { allaborans (Walker, } \\
\text { 1859) }\end{array}$ & & & & & & & & & 1 & & & 1 & 1 \\
\hline & \multicolumn{3}{|c|}{ Total number of individual } & $\begin{array}{l}33 \\
6 \\
\end{array}$ & $\begin{array}{l}128 \\
9\end{array}$ & $\begin{array}{l}151 \\
0\end{array}$ & $\begin{array}{l}112 \\
1\end{array}$ & 931 & $\begin{array}{l}231 \\
6\end{array}$ & $\begin{array}{l}36 \\
9\end{array}$ & 62 & 19 & 40 & 8 & & \\
\hline & \multicolumn{3}{|c|}{ Total number of species } & 25 & 34 & 35 & 19 & 32 & 42 & 10 & 8 & 4 & 40 & 8 & & \\
\hline
\end{tabular}

